\title{
LONGITUDINAL VARIATION OF RING WIDTH, WOOD DENSITY AND BASAL AREA INCREMENT IN 26-YEAR-OLD LOBLOLLY PINE (PINUS TAEDA) TREES
}

\author{
MUKUI YU ${ }^{1}$, XIANGRONG CHENG ${ }^{1}$, ZHENXIANG HE $^{2 *}$, TONGGUI WU ${ }^{1}$, and ZENGFANG YIN ${ }^{3 *}$ \\ ${ }^{1}$ Institute of Subtropical Forestry, Chinese Academy of Forestry, East China Research Station of Coastal Shelter Forest \\ Ecosystem, Fuyang, Zhejiang, 311400, P. R. China \\ ${ }^{2}$ State Key Lab. of Pharmaceutical Biotechnology, School of Life Science, Nanjing University, Nanjing, Jiangsu, 210093, P. R. China \\ ${ }^{3}$ College of Forest Resources and Environment, Nanjing Forestry University, Nanjing, Jiangsu, 210037, P. R. China
}

\begin{abstract}
Longitudinal variations in select wood quality parameters were examined in 26-year-old loblolly pine trees planted in Anhui Province, China. Wood density and ring width were measured from crosssections of different heights of merchantable stems. The average ring width decreased from the base to $1.3 \mathrm{~m}$, then increased to the maximum at $7.6 \mathrm{~m}$, and thereafter reduced with stem height. The longitudinal patterns varied with cambial age in ring width. The coefficient of variation in ring widths along the stem height was greater than $21 \%$ at the cambial age 5-8 years and 9-12 years, and small variations were observed in other cambial age groups. The average wood density declined from $1.3 \mathrm{~m}$ to $7.6 \mathrm{~m}$ and then slightly increased with increasing stem height. The wood density showed great variation at different growth stages below $7.6 \mathrm{~m}$, but varied less above $7.6 \mathrm{~m}$. Basal area increment (BAI) gradually increased with increasing ring number (from the pith to the bark) at different stem heights, and markedly reduced after the $22^{\text {nd }}$ ring. These results indicate that the longitudinal variations of wood density, ring width and BAI in loblolly pine are greatly affected by cambial age. The detailed information of the wood properties along stem heights could be useful to wood utilization of loblolly pine.
\end{abstract} variation.

Keywords: loblolly pine, ring width, wood density, basal area increment (BAI), longitudinal

\section{INTRODUCTION}

Loblolly pine (Pinus taeda L.), native to the southeastern United States, is an important timber species (McKeand et al. 2003). It has been widely planted in the tropical and sub-tropical regions around the world, such as in South Africa, New Zealand, Australia and Brazil. Loblolly pine was first introduced in China in the 1930s. Because of its favorable properties, especially its rapid growth and wide adaptability, loblolly pine has become a major tree species for construction and pulp timber in the south of China with a yearly plantation area of 200,000 ha (Xu et al. 2008).

\footnotetext{
*Corresponding authors: zxhe@nju.edu.cn; Telephone: 86-25-8359-2705, and zfyin@njfu.edu.cn; Telephone: +86$25-85427316$
}

Wood density and ring width are the most commonly used indicators of wood characteristics. Wood density is considered the key index for wood quality, pulp yield and quality (Bendtsen 1978), whereas ring width is related to the volume of wood produced as well as end product uniformity (Park et al. 2009). Additionally, many studies have shown that annual basal area increment (BAI) (Le Blanc 1990), another measure of radial growth, is well suited to represent individual and stand-level changes (Bigler and Bugmann 2003; Piovesan et al. 2008; Voelker et al. 2008).

The detailed radial variations in wood density were studied for many conifers and hardwood trees species (e.g. Panshin and de Zeuuw 1980; Jozsa and Middleton 1994; Kennedy 1995). However, most of these studies were performed 
at breast height. There are relatively few data available on radial variation in wood density at different stem heights (Park et al. 2009). Previous studies showed that the longitudinal variation of wood density tended to decrease with stem height (Singh 1984, 1986) mainly because the proportion of juvenile wood increased with stem height (Zobel and Sprague 1998). Some studies showed that ring width had an increasing trend with stem height in loblolly pine (Megraw 1986; Tasissa and Burkhart 1997; Gartner et al. 2002). These results suggest that wood properties vary with stem position.

However, the patterns vary considerably and sometimes contradictorily, even for the same species. For example, some studies showed that ring density had an increasing trend with stem height in Norway spruce (Picea abies) (Molteberg and Høibø 2006; Jyske et al. 2008), but Mäkinen et al. (2007) found no significant height effect on ring density. Megraw (1985) showed that the longitudinal patterns of wood density in loblolly pine were dependent on radial position or cambial age. Additionally, many studies on BAI growth of individual trees were only performed at breast height. Little is known about the variation of BAI at different growth stages and at different stem heights. To effectively utilize wood, it is necessary to understand the detailed information of the wood on the within-stem position.

The objectives of this study were to (1) examine the patterns of ring width, wood density, and basal area increment along stem height, and (2) relate longitudinal patterns in ring width and wood density to tree cambial age.

\section{MATERIALS AND METHODS}

\section{Site Description}

The experiment was conducted at the Matou forest farm $\left(118^{\circ} 32^{\prime} \mathrm{E}, 30^{\circ} 45^{\prime} \mathrm{N}\right)$ in Jing County, Anhui Province, China. Typical of a subtropical monsoon climate in the study site, the mean annual temperature is $15.7^{\circ} \mathrm{C}$, mean annual precipitation is $1553 \mathrm{~mm}$, and the frost-free period is 239 days. The soil type is a yellow-red soil evolving from Quaternary red clay with a sticky texture and medium fertility. The original vegetation of this area was naturally scattered Pinus massoniana.

The experimental loblolly pine forest was planted in the spring of 1969 at an original stand density of 1200 trees per ha. The stand was thinned in 1982 (stand density reduced by approximately $25 \%$ ). The stand density at the time of this study was 850 trees per ha. The slope of the experimental area is approximately $20 \%$ with a northeastern aspect. Three average trees (tree height is $17.4 \mathrm{~m}$, $16.1 \mathrm{~m}$ and $15.6 \mathrm{~m}$, respectively; diameter at breast height is $33.78 \mathrm{~cm}, 33.78 \mathrm{~cm}, 29.03 \mathrm{~cm}$, respectively; vertical span of living crown is $8.5 \mathrm{~m}, 7.6 \mathrm{~m}$ and $7.2 \mathrm{~m}$, respectively) were randomly selected for sampling in March, 1995. Loblolly pine was cultivated for industrial timber (e.g. plywood and construction lumber) in the experimental area.

\section{Measurement of Growth Ring Width}

After felling the trees, we marked the node from tree base to the top at $0 \mathrm{~m}, 1.3 \mathrm{~m}, 3.6 \mathrm{~m}$, $5.6 \mathrm{~m}, 7.6 \mathrm{~m}, 9.6 \mathrm{~m}, 11.6 \mathrm{~m}, 13.6 \mathrm{~m}$, and $14.6 \mathrm{~m}$ along the tree stem. Nine tree stem disks of $5 \mathrm{~cm}$ thickness were taken from these heights. A straight line was marked through the pith in the southnorth and east-west directions. We measured the width of each ring (earlywood width and latewood width) in the east, south, north and west directions by using measuring meter of tree-ring width (LINTAB) with $0.01 \mathrm{~mm}$ accuracy, and tested results of crossdating and measurement by adopting COFECHA procedures (Holmes 1983).

\section{Measurement of the Wood Density of a Disk}

With the wood pith at the center, fan-shaped wood blocks at $30^{\circ}$ angles with directions clearly marked were intercepted from the pith to the cambial in four directions and dipped in water for 40 days to stabilize the size by absorbing moisture. Then, ring samples, each representing two years, were cut from bark to pith with a wood chisel. Surfaces were kept wet for the measurements, so that the wood density was measured using the water immersion method (Hein et al. 2009). Samples were subsequently oven-dried at the 


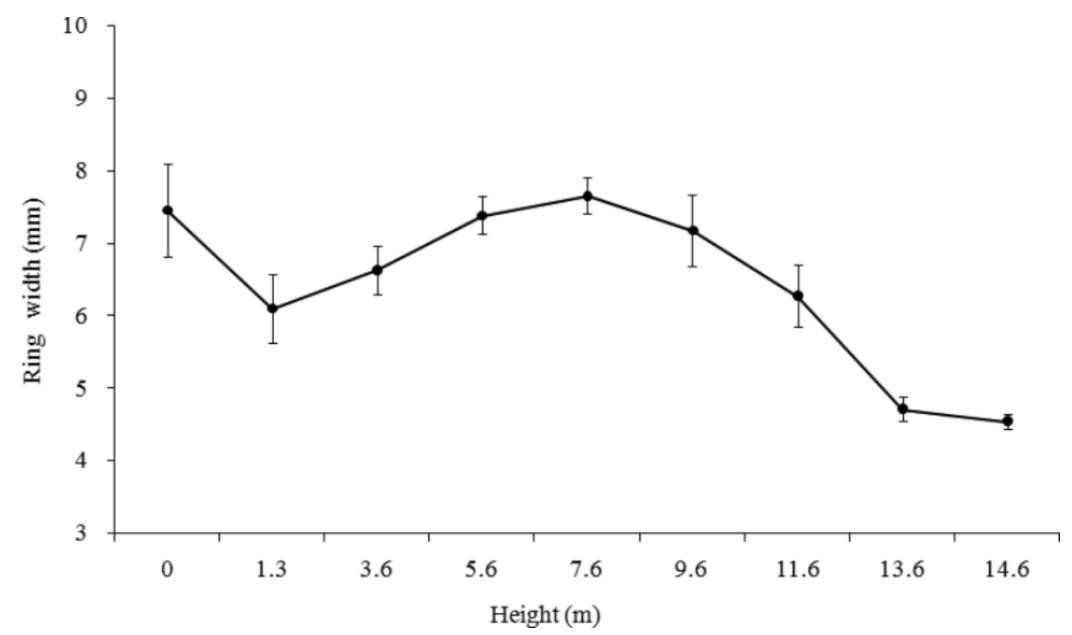

Figure 1. Longitudinal variation of the average annual ring width in 26-year-old loblolly pines (n varies from 312 at the bottom to 36 at the top, mean $\pm \mathrm{SE}$ ).

temperature of $103^{\circ} \mathrm{C}$ until the mass was constant. The dry matter content was determined to $0.001 \mathrm{~g}$ accuracy. The wood density $(\mathrm{G})$ was defined as:

$$
\mathrm{G}=\mathrm{M} / \mathrm{V}
$$

where $\mathrm{M}$ is the sample dry weight ( $\mathrm{g}$ ) and $\mathrm{V}$ is the sample volume with water saturation $\left(\mathrm{cm}^{3}\right)$.

\section{Calculation of the Basal Area Increment (BAI)}

Because BAI at year $t$ is equivalent to annual ring area (Biondi and Qeadan 2008), so it can be calculated with following equation:

$$
\mathrm{BAI}=\pi\left(\mathrm{R}_{\mathrm{t}}^{2}-\mathrm{R}_{\mathrm{t}-1}^{2}\right)
$$

where $R_{t}$ is the stem radius at the end of the annual increment, and $\mathrm{R}_{\mathrm{t}-1}$ is the stem radius at the beginning of the annual increment.

\section{Data Analysis}

Radial profiles of wood density, ring width and basal area increment were produced for each disk. Wood density and ring width at each stem height were the mean of all trees in the four directions. To determine the change of growth ring and wood density at different growth stages (cambial age) along the stem height, the growth rings were classified into several groups by cambial age. Each group contains four growth rings.

\section{RESULTS}

\section{Longitudinal Variation in Ring Width}

The average ring width decreased from the base to $1.3 \mathrm{~m}$, but increased and reached the maximum at $7.6 \mathrm{~m}$, and then reduced with stem height (Figure 1). The ring width varied from $4.54 \mathrm{~mm}$ to $7.66 \mathrm{~mm}$ among nine stem heights, and the average value was $6.44 \mathrm{~mm}$. Longitudinal variation of the annual ring width greatly differed among different ring ages (Figure 2). Annual ring width generally decreased from the base to $1.3 \mathrm{~m}$ at different cambial age groups. Ring width increased above $1.3 \mathrm{~m}$ and then declined near the top at the age groups of $1-4$ years, 5-8 years and 9-12 years. Tree-ring width consistently decreased with stem height at 13-16 years, while it increased from $1.3 \mathrm{~m}$ to $3.6 \mathrm{~m}$ at the $17-20$ years. The mean ring width was $4.71 \mathrm{~mm}$ at $1-4$ years, which was lower than other cambial age groups $(6.52$ $8.13 \mathrm{~mm}$, except $1.93 \mathrm{~mm}$ at the $25-26$ years). The coefficient of variation in ring width along the stem height was $21.84 \%$ and $23.19 \%$ for cambial age 5-8 years and 9-12 years, respectively, and it varied from $10.37 \%$ and $16.19 \%$ in other cambial age groups. Especially, the younger cambium age (1-4 years) showed less variation with stem height. 


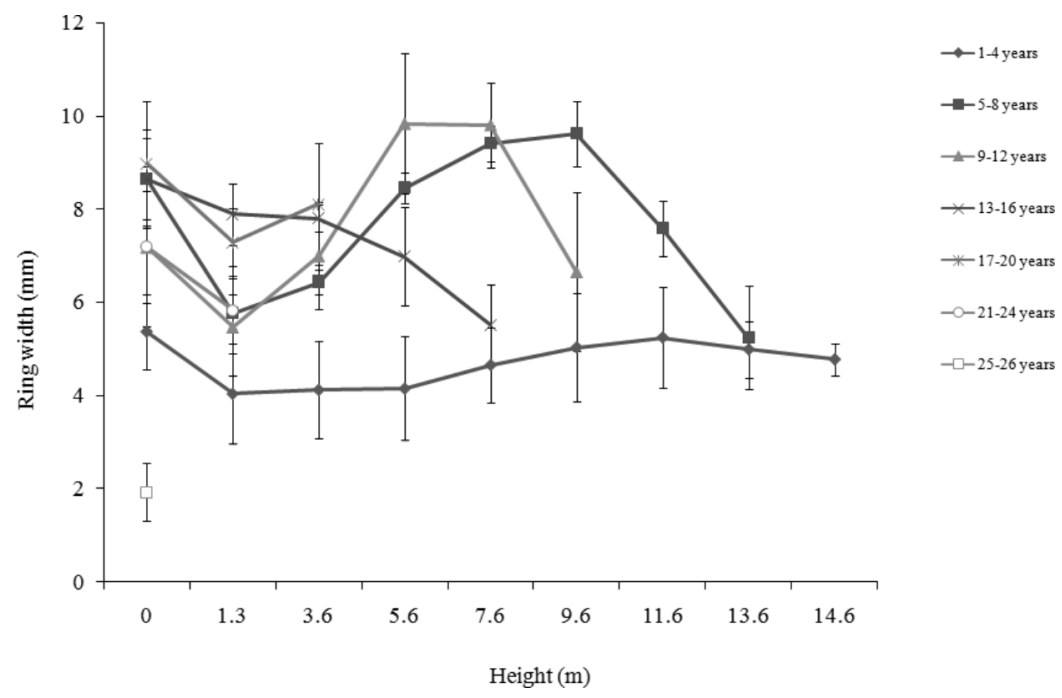

Figure 2. Longitudinal variation of the annual ring width by cambial age groups $(\mathrm{n}=12$, mean $\pm \mathrm{SE})$.

\section{Longitudinal Variation in Wood Density}

Longitudinal variations in wood density at different heights are shown in Figure 3. From the tree base to the top, the average wood density was high below $1.3 \mathrm{~m}$. It declined from $1.3 \mathrm{~m}$ to $7.6 \mathrm{~m}$, reaching a minimum of $0.33 \mathrm{~g} \mathrm{~cm}^{-3}$, and then slightly increased with stem height (except for a sudden increase at $11.6 \mathrm{~m}$ ). Overall, the average wood density presented a decreasing trend with stem height. The pattern of longitudinal variations in wood density was similar at different cambial age groups (Figure 4). The wood density showed great variation at different growth stages below $7.6 \mathrm{~m}$, and less variation was found above $7.6 \mathrm{~m}$.

\section{Longitudinal Variation in Basal Area Increment}

Temporal variations of basal area increment (BAI) at different heights of loblolly are shown in Figure 5. The variation pattern of BAI was similar

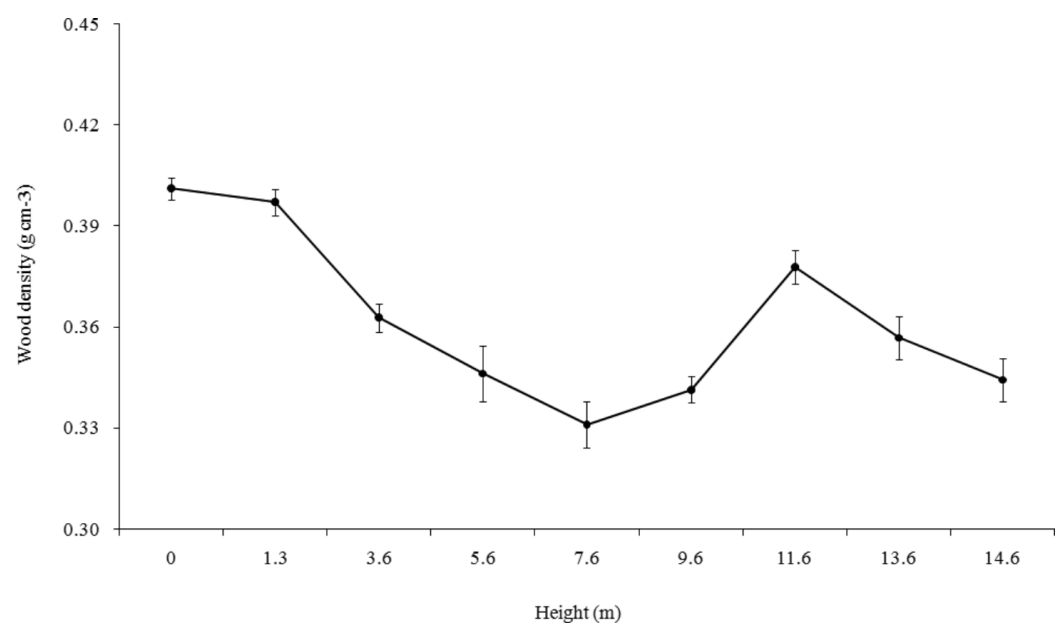

Figure 3. Longitudinal variation of the wood density in 26-year-old loblolly pines (n varies from 156 at the bottom to 12 at the top, mean $\pm \mathrm{SE})$. 


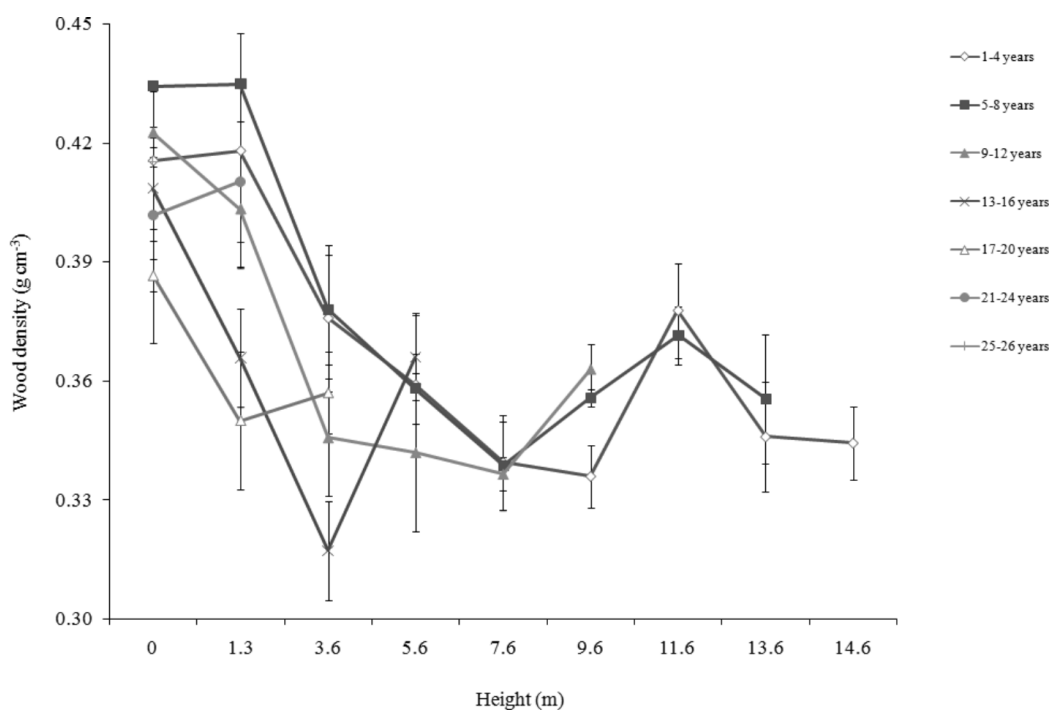

Figure 4. Longitudinal variation of the wood density by cambial age groups $(n=12$, mean $\pm \mathrm{SE})$.

from the base $(0 \mathrm{~m})$ to $11.6 \mathrm{~m}$ stem height. BAI was low near the pith, gradually increased to reach a maximum at about the $22^{\text {nd }}$ ring (except for a sudden decline from the $17^{\text {th }}$ to $19^{\text {th }}$ ring), and then markedly reduced after the $22^{\text {nd }}$ ring. However, the magnitude of variations in BAI was different within each stem height. BAI increased with ring number at the $13.6 \mathrm{~m}$ and $14.6 \mathrm{~m}$ stem height. The value of BAI at the $26^{\text {th }}$ ring was $19.06 \mathrm{~cm}^{2} \mathrm{yr}^{-1}$ at $1.3 \mathrm{~m}$, which was $38.50 \%$ of the maximum $\left(49.52 \mathrm{~cm}^{2} \mathrm{yr}^{-1}\right.$, at the $22^{\text {nd }}$ ring).

\section{DISCUSSION}

\section{Variation of Ring Width in Loblolly Pine}

Ring width reflects the speed of tree growth, while the growth rate has a direct impact on timber productivity and wood quality. Previous studies found little longitudinal variation in ring width or wood density (Duff and Nolan 1953; Olesen 1982; Mäkinen et al. 2007). However, in this study, a clear height effect was observed for ring width during the study period. Ring widths

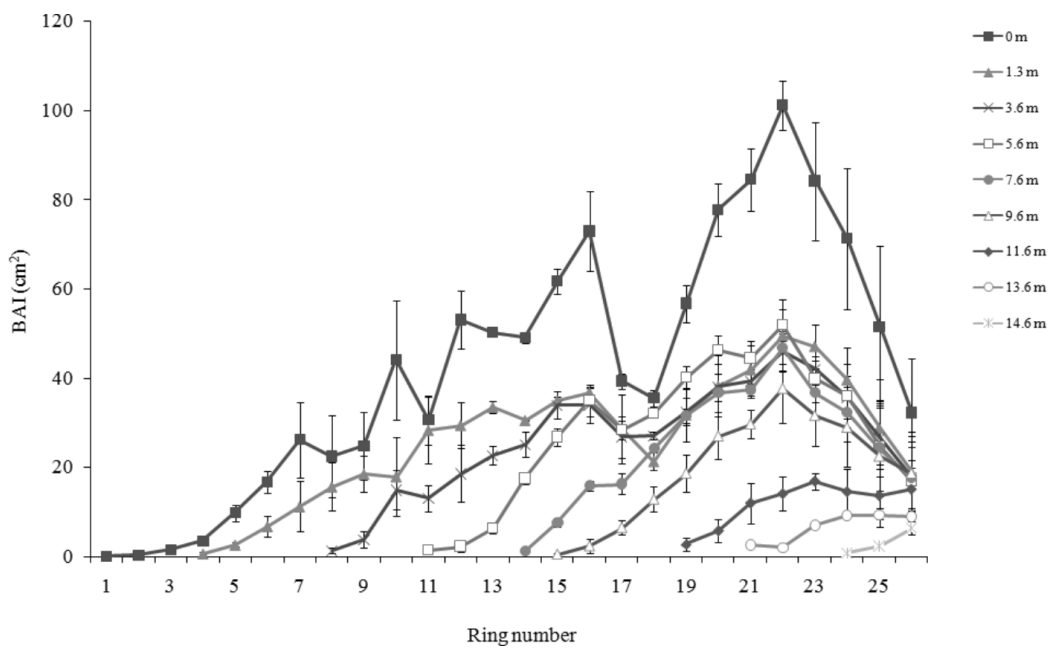

Figure 5. Variations of basal area increment (BAI) with ring number (from pith to bark) at $0 \mathrm{~m}, 1.3 \mathrm{~m}, 3.6 \mathrm{~m}, 5.6 \mathrm{~m}, 7.6 \mathrm{~m}, 9.6 \mathrm{~m}$, $11.6 \mathrm{~m}, 13.6 \mathrm{~m}$ and $14.6 \mathrm{~m}$ height $(\mathrm{n}=3$, mean $\pm \mathrm{SE})$. 
generally increased from $1.3 \mathrm{~m}$ upward and declined near the top (Figure 2). Great variations were found for tree-ring width along the stem heights at cambial age 5-8 years and 9-12 years, whereas small variations were observed at other cambial age groups. The tree rings in the middlebottom of the living crown (approximate half of tree height) were markedly wider than the lower stem at cambial age 5-8 years and 9-12 years. After age 12, ring width constantly decreased almost linearly from the base to the top. However, some studies showed that there was a clear trend of decreasing growth ring width from the tree top downward, with growth rings being wider within the crown than below the crown (Megraw 1986; Gartner et al. 2002). Tasissa and Burkhart (1997) showed that ring width of 25-year-old loblolly pine decreased with increasing height and reached a minimum close to the $1.3 \mathrm{~m}$ height from where it gradually increased until the vicinity of living crown. Trees first allocate photosynthate in the actively growing region of the crown. As trees grow and the lower branches become less efficient and begin to die, the point of maximum growth shifts upward (Tasissa and Burkhart 1997). Once the need for growth and photosynthesis has been met in the actively growing region of the crown, materials are transported down the stem for storage and other needs (Kozlowski 1971). Although trees having more resources because of less competition can transport materials down the stem for diameter growth, those that are subject to more intense competition use up their resources within the vicinity of the live crown. These results indicate that, at a given cambial age, tree-ring widths have great variation at different stem heights.

\section{Variation of Wood Density in Loblolly Pine}

Wood density reflects the amount of substances in the wood cell wall and constitutes an important property in tree breeding. The longitudinal variation in wood density of loblolly pine was reported in several studies. Early studies reported a decrease in wood density from stumpto-tip of the loblolly pine tree (Megraw 1985; Zobel and van Buijtenen 1989). A typical pattern of wood density with stem height for loblolly pine, as reported by Pearson and Gilmore (1971), is that wood density decreased from $3 \mathrm{ft}$. (ca. $0.9 \mathrm{~m})$ to $23 \mathrm{ft} .(c a .7 .0 \mathrm{~m})$ and reached a minimum, and then slightly increased with stem height. In this study, the pattern of longitudinal variation in wood density had similar trends with Pearson and Gilmore's result. Although wood densities showed great variation at different cambial age groups below the $7.6 \mathrm{~m}$ stem height, especially at the base and $1.3 \mathrm{~m}$, they varied little at different cambial age groups above $7.6 \mathrm{~m}$. This suggests that the longitudinal patterns of wood density in loblolly pine were dependent on stem height and cambial age. Park et al. (2009) also found that cambial age greatly affected the patterns of wood density with stem height in jack pine (Pinus banksiana). In their study, wood density increased from stem base to top at cambial age 2 years. After age 10, wood density constantly decreased almost linearly from stem base to the top. However, Antony et al. (2010) reported that longitudinal variation of wood density with stem height can be divided into three segments based on investigation of the natural range of loblolly pine (20-25 years old). The average wood density decreased rapidly from the base of the tree to a relative height of $c a$. 0.1 ; it then decreased at a decreasing rate between relative heights of $c a$. 0.1 to 0.3 ; for relative heights $>c a$. 0.3 , wood density decreased at constant rate.

Marked longitudinal and regional variation in wood density has been reported for loblolly pine by Jordan et al. (2008) and Antony et al. (2010). The average wood density of the whole tree was $0.36 \mathrm{~g} \mathrm{~cm}^{-3}$ (ranged from $0.31 \mathrm{~g} \mathrm{~cm}^{-3}$ to $0.41 \mathrm{~g} \mathrm{~cm}^{-3}$ ) for 26-year-old loblolly pine in the current study. The wood density varied from $0.34 \mathrm{~g} \mathrm{~cm}^{-3}$ to $0.58 \mathrm{~g} \mathrm{~cm}^{-3}$ for loblolly pine (2025 years old) in the USA. The mean wood density observed for the southern Atlantic Coastal Plain and Gulf Coastal Plain was $0.46 \mathrm{~g} \mathrm{~cm}^{-3}$, and it was $0.42 \mathrm{~g} \mathrm{~cm}^{-3}$ for the other regions (Antony et al. 2010). The wood density in our results was lower than that of the research of Antony et al. The reason for their higher wood density might partly result from the increased latewood percentage (35-40\%) of these trees (Antony et al. 2010). The average latewood percentage was $24.9 \%$ in our study. 


\section{Variation of Basal Area Increment in Loblolly Pine}

The BAI growth of individual trees typically follows a sigmoidal pattern: BAI increases rapidly from young to middle age, remains at a constant level during a protracted period of middle age and then reduces as trees become old (Weiner and Thomas 2001). In the current study, we observed a similar result. The BAI gradually increased with increasing ring number, reached a maximum at the $22^{\text {nd }}$ ring, and reduced thereafter for stem heights from $0 \mathrm{~m}$ to $9.6 \mathrm{~m}$, whereas it initially increased with increasing ring number and remained at a constant level thereafter for stem heights above $9.6 \mathrm{~m}$. This BAI trend may be related to an increasing tree canopy during early age, a constant canopy volume during middle age, and then a physiological decline in old trees (Spiecker et al. 1996). Recently, an increasing number of studies have demonstrated that decline of tree growth with tree age and size is closely linked with physiological processes, including declines in gas exchange, photosynthesis, and growth rate (Koch et al. 2004; Ryan et al. 2006; Greenwood et al. 2008). As tree height increases, water must overcome additional gravitational and frictional forces to reach the top. Eventually resistance becomes so great that leaf water stress increases, inducing stomata to close, thereby limiting gas exchange and photosynthesis, and ultimately reducing growth (Delzon and Loustau 2005; Ryan et al. 2006). Drake et al. (2010) also confirmed that "hydraulic limitation" could explain a decline of growth rate with increasing age (or size) in loblolly pine.

The variation of ring width, wood density and BAI in loblolly pine might also be influenced by climate changes (e.g. precipitation and temperature) (Rossi et al. 2008; Vieira et al. 2009; Li et al. 2012). However, the climate in the study area did not show great fluctuation during the study period except for a few individual years (Fang and Ji 2008). The knowledge of longitudinal patterns of wood properties in loblolly pine has many useful applications for wood production and wood utilization. For example, pulp wood production and use of wood for furniture and construction could be more accurately evaluated.

\section{ACKNOWLEDGMENTS}

This project was supported by the national agriculture science and technology achievement transformation foundation (2013GB24320618). Our thanks also go to Prof. Geoff Wang, Ms. Xiaoyan Wang and Dr. Yi Dong for their help revising the manuscript.

\section{REFERENCES CITED}

Antony, F., L. R. Schimleck, R. F. Daniels, A. Clark, III, and D. B. Hall, 2010. Modeling the longitudinal variation in wood specific gravity of planted loblolly pine (Pinus taeda) in the United States. Canadian Journal of Forest Research 40: 2439-2451

Bendtsen, B. A., 1978. Properties of wood from improved and intensively managed trees. Forest Products Journal 28:61-72.

Bigler, C., and H. K. M. Bugmann, 2003. Growth-dependent tree mortality models based on tree rings. Canadian Journal of Forest Research 33:210-221.

Biondi, F., and F. Qeadan, 2008. A theory-driven approach to tree-ring standardization: Defining the biological trend from expected basal area increment. Tree-Ring Research 64:81-96.

Delzon, S., and D. Loustau, 2005. Age-related decline in stand water use: Sap flow and transpiration in a pine forest chronosequence. Agricultural and Forest Meteorology 129: 105-119.

Drake, J. E., L. M. Raetz, S. C. Davis, and E. H. De Lucia, 2010. Hydraulic limitation not declining nitrogen availability causes the age-related photosynthetic decline in loblolly pine (Pinus taeda L.). Plant, Cell and Environment 33:17561766.

Duff, G. H., and N. J. Nolan, 1953. Growth and morphogenesis in the Canadian forest species I. The control of cambial and apicalactivity in Pinus resinosa Ait. Canadian Journal of Botany 31:471-513.

Fang, S. Q., and C. Ji, 2008. Research on climatic condition and trend in Xuancheng. Journal of Anhui Agriculture Science 36(7):2891-2892. (In Chinese)

Gartner, B. L., E. M. North, G. R. Johnson, and R. Singleton, 2002. Effects of live crown on vertical patterns of wood density and growth in Douglas-fir. Canadian Journal of Forestry Research 32:439-447.

Greenwood, M. S., M. H. Ward, M. E. Day, S. L. Adams, and B. J. Bond, 2008. Age-related trends in red spruce foliar plasticity in relation to declining productivity. Tree Physiology 28:225-232.

Hein, P. R. G., A. C. M. Campos, P. F. Trugilho, J. T. Lima, and G. Chaix, 2009. Near infrared spectroscopy for estimating wood basic density in Eucalyptus urophylla and Eucalyptus grandis. Cerne, Lavras 15(2):133-141.

Holmes, R. L., 1983. Computer-assisted quality control in treering dating and measurement. Tree-Ring Bulletin 43:69-78.

Jordan, L., A. Clark, L. R. Schimleck, D. B. Hall, and R. F. Daniels, 2008. Regional variation in wood specific gravity of 
planted loblolly pine in the United States. Canadian Journal of Forest Research 38:698-710.

Jozsa, L. A., and G. R. Middleton, 1994. A Discussion of Wood Quality Attributes and their Practical Implications. Forintek Canada Corp, Vancouver, Canada; 42 pp.

Jyske, T., H. Mäkinen, and P. Saranpää, 2008. Wood density within Norway spruce stems. Silva Fennica 42:439-455.

Kennedy, R. W., 1995. Coniferous wood quality in the future: Concerns and strategies. Wood Science and Technology 29: 321-338.

Koch, G. W., S. C. Sillett, G. E. Jennings, and S. D. Davis, 2004. The limits to tree height. Nature 428:851-854.

Kozlowski, T. T., 1971. Leaf growth and development. In Growth and Development of Trees. Volume I. Seed Germination, Ontogeny, and Shoot Growth, Printer Errors T. T. Kozlowski, pp. 207-244. Academic Press, London, UK.

LeBlanc, D. C., 1990. Relationships between breast-height and whole-stem growth indices for red spruce on Whiteface Mountain, New York. Canadian Journal of Forest Research 20:1399-1407.

Li, Z. S., Q.-B. Zhang, and K. Ma, 2012. Tree-ring reconstruction of summer temperature for A.D. 1475-2003 in the central Hengduan Mountains, Northwestern Yunnan, China. Climatic Change 110(1-2):455-467.

Mäkinen, H., T. Jaakkola, R. Piispanen, and P. Saranpää, 2007. Predicting wood and tracheid properties of Norway spruce. Forest Ecology and Management 241:175-188.

McKeand, S., T. Mullin, T. Byram, and T. White, 2003. Deployment of genetically improved loblolly and slash pines in the south. Journal of Forestry 101(3):32-37.

Megraw, R. A. (ed.), 1985. Wood Quality Factors in Loblolly Pine. Tappi Press, 88 pp.

Megraw, R. A., 1986. Douglas-fir wood properties. In Proceedings, Douglas-fir: Stand Management for the Future, Printer Errors C. D. Oliver, D. P. Hanley, and J. A. Johnson, pp. 81-96. Institute of Forest Resources, University of Washington, Seattle, Contribution 55.

Molteberg, D., and O. Høibø, 2006. Development and variation of wood density, kraft pulp yield and fibre dimensions in young Norway spruce (Picea abies). Wood Science and Technology 40(3):173-189.

Olesen, P. O., 1982. The Effect of Cyclophysis on Tracheid width and Basic Density in Norway Spruce (Forest Tree Improvement). Akademisk Forlag, Copenhagen; 80 pp.

Panshin, A. J., and C. de Zeeuw, 1980. Textbook of Wood Technology. McGraw-Hill Book Company, New York, NY; $722 \mathrm{pp}$.

Park, Y., A. Koubaa, S. Brais, and M. J. Mazerolle, 2009. Effects of cambial age and stem height on wood density and growth of jack pine growth in boreal stands. Wood and Fiber Science 41(4):346-358.

Pearson, R. G., and R. C. Gilmore, 1971. Characterization of the strength of juvenile wood of loblolly pine (Pinus taeda L.). Forest Products Journal 21(1):23-31.

Piovesan, G., F. Biondi, A. Di Filippo, A. Alessandrini, and M. Maugeri, 2008. Drought-driven growth reduction in old beech (Fagus sylvatica L.) forests of the central Apennines, Italy. Global Change Biology 14:1265-1281.

Rossi, S., A. Deslauriers, T. Anfodillo, and M. Carrer, 2008. Age-dependent xylogenesis in timberline conifers. New Phytologist 177:199-208.

Ryan, M. G., N. Phillips, and B. J. Bond, 2006. The hydraulic limitation hypothesis revisited. Plant, Cell and Environment 29:367-381.

Singh, T., 1984. Variation in the oven dry wood density often prairie tree species. The Forestry Chronicle 60:217-221.

Singh, T., 1986. Wood density variation of six major tree species of the Northwest Territories. Canadian Journal of Research 16:127-129.

Spiecker, H., K. Mielikaeinen, M. Kohl, and P. Skovsgaard. (eds.), 1996. Growth Trends in European Forests: Studies from 12 Countries. European Forest Institute Research Report No. 5. Springer, Berlin, Germany.

Tasissa, G., and H. E. Burkhart, 1997. Modeling thinning effects on ring width distribution in loblolly pine (Pinus taeda). Canadian Journal of Forest Research 27:1291-1301.

Vieira, J., F. Campelo, and C. Nabais, 2009. Age-dependent responses of tree-ring growth and intra-annual density fluctuations of Pinus pinaster to Mediterranean climate. Trees 23(2):257-265.

Voelker, S. L., R.-M. Muzika, and R. P. Guyette, 2008. Individual tree and stand level influences on the growth, vigor, and decline of red oaks in the Ozarks. Forest Science 54:8-20.

Weiner, J., and S. C. Thomas, 2001. The nature of tree growth and the age-related decline in forest productivity. Oikos 94 : 374-376.

Xu, Y. M., Z. H. Jiang, L. X. Li, Q. Z. Zhao, M. Dai, and H. Q. Ren, 2008. Variation in wood properties of different provenances of exotic loblolly pine for pulpwood. Scientia Silvae Sinicae 44(8):82-89. (In Chinese)

Zobel, B. J., and J. P. van Buijtenen, 1989. Wood Variation: Its Causes and Control. Springer-Verlag, Berlin, Germany; 363 pp.

Zobel, B. J., and J. R. Sprague, 1998. Juvenile Wood in Forest Trees. Springer-Verlag, Berlin, Germany; 300 pp.

Received 7 November 2012; accepted 28 February 2014. 